\title{
The Impact of Social Media Technologies on the Revolutions
}

\author{
Ahmed Al-Abdin ${ }^{1}$, Robert Costello ${ }^{2}$ \\ ${ }^{1}$ Hull University Business School, University of Hull, Hull, United Kingdom \\ ${ }^{2}$ Graduate School, University of Hull, Hull, United Kingdom \\ Email address: \\ Ahmed.Al-Abdin@hull.ac.uk (A. Al-Abdin), r.costello@hull.ac.uk (R. Costello)
}

\section{To cite this article:}

Ahmed Al-Abdin, Robert Costello. The Impact of Social Media Technologies on the Revolutions. Humanities and Social Sciences. Vol. 3, No. 3, 2015, pp. 116-124. doi: 10.11648/j.hss.20150303.13

\begin{abstract}
In this paper, we analyse the impact of social media technology on the Arab spring, and how individuals and communities used Schemata of Interpretation and Human Factor (cause, justification and emotions) to support the uprising throughout the Middle East. Social Media enabled activists from different regions to use technologies to share ideas and tactics, to inspire and engage protesters aspirations and to resonate from rural areas to gather at centrally located points push the momentum. Using social media the activists were able to distribute key messages for collective action and contribute to awareness and discussion from different political factions to create social anarchy, chaos, cultural imagery and symbolisms. By creating social anarchy activists can forge mutual friendship by individuals within the group through sharing belief and culture. The Causes \& Technologies framework being presented here looks at the human factor and identifies key traits and themes that are necessary for Actors within the society to form necessary uprisings.
\end{abstract}

Keywords: Uprising, Social Media, Activists, Arab Spring, Schemata of Interpretation, Human Factor

\section{Introduction}

The recent and continuing uprising commonly known as the 'Arab Spring' is developing as an important global phenomenon, particular for Arab citizens. For years, authoritarian regimes have held the higher ranks have accumulated power within a boundary and one which citizens could not breach for fear of being punished. The Arab Spring took many by surprise as people across the regime assembled together to topple incumbent regimes. To achieve change, citizens used a variety of tools such as social media to disseminate a united message to the masses. Therefore, in this paper, social media is taken as the focus and considered to be one of the catalysts of the revolution. The aim of this paper is to assess the impact of social media and its effectiveness in bringing about change. First, an analysis of current upheavals in the Middle East (ME) is presented. Owing to the continuous unrest that is taking place, it is likely that much of this literature will become historic news as extraordinary change continues. Importantly, the aim of the next section is not to take a personal bias but to provide a summary of the Arab Spring to date and highlight the main drivers of change.

Initially, the term 'Arab Spring' emerged as part of US strategy in maintaining strategic aims and objectives as part of pushing for an American style democracy (Anderson, 2011; Massad, 2011). Metaphorically speaking, the term Arab Spring is treated cautiously in this paper because many springs have indeed come and gone since the first uprising in Tunisia in December 2010. Therefore, the term 'revolution' is used henceforth as it is more appropriately suited to periods of high environmental flux. Furthermore, the term revolution is also treated with caution because the revolutions in different ME states and their citizens caught up in the uprisings have been subsequent to varying scenarios ranging from mass protests and demonstrations (e.g. Tunisia and Egypt) to more violent movements and bouts of civil war (e.g. Libya). Historic revolutions such as the French revolution (1789-1799collapse of the French monarchy), the American revolution (late $18^{\text {th }}$ century- break away from the British empire and subsequent formation of the United States of America), the Taiping revolution in China (1851-1864 against the authority and forces of the Qing Empire), the Chinese revolution (1911-1949- Communist party rule and formation of the People's Republic of China) and the Iranian revolution (1978-1979- removal of Iran's monarchy or Pahlavi dynasty) have resulted in mixed fortunes. Whilst some have led to more progressive states and subsequent country development, 
others have ended up far worse. For instance, the collapse and transition from communism to emerging powers in Eastern Europe in the nineties paved waves for free-market capitalism (Bremmer 2010) that enabled citizens to critique the state in a way that was not previously possible. On the other hand, revolutions can also fail but their failure is subject to debate and not deliberated here. Argyrou (2013) provides a useful critique of revolutions and argues that they always returned to an earlier state of affairs or prior point of departure and restored governmental figures far worse from those that the revolution was meant to overturn. Moreover, he suggests that revolutions revolve around an iterative cycle in that they go round and come back around. This is also known as an epiphenomenon (a phenomenon after a phenomenon). The aim of a revolution according to Arendt (2006) is freedom because man is considered to be born free and freedom is a natural right. If this is the case, then a question to ask here is how did citizens during the Arab revolutions use social media to bring about revolutionary change?

\section{Unveiling the Silhouette Behind the Arab Spring: A Spark of Candidness}

On the $17^{\text {th }}$ December 2010, Tunisian citizens marched together to protest for the removal of the then president Zine El Abidine Ben Ali whose authoritarian regime span several decades (Tadros, 2012). One of the catalysts of the Tunisian revolution was when a street vendor known as Mohammed Bouazizi set himself on fire amid several altercations with local authorities who attempted to take away his livelihood (Noueihed and Warren, 2012). Mass protests and demonstrations ensued and later saw the subjugation of Tunisia's president Zine El Abidine Ben Ali. Bouazizi, meanwhile became known as a hero and is considered one of the catalysts behind the Tunisian revolution. Citizens had grown restless of mass corruption, nepotism and the inexistence of political lucidity (Hashemi, 2011; Sakbani, 2011).

About $60 \%$ of the ME's population is under years of age 30 . These young people shared aspirations for change (Inayatullah, 2011) and filled the streets to voice their anger and fight against political regimes (Lynch, 2011). In particular, the revolutions were popular amongst the youth because they had never ever experienced a revolution or indeed regime change (Daou, 2011). Khalid Al Qashtaini, an Iraqi writer in London, developed the following equation for change in the ME: education + freedom of thought $=$ awakening + salvation (Cited in Butt, 2011). To critically appraise the author's assumption, this equation seems worthy of critical merit and validity. However, if one was to challenge this view and reverse the equation, how would awakening the people's mind-sets and salvaging their own opinions affect their education (intellectuality) and freedom of thought? Moreover, from a personal standpoint, the consequences of salvation would seem to produce greater freedom of thought and so freedom of expression becomes an actor of change.
According to Anderson (2011, p.2), young people from across different regions used technologies to "share ideas and tactics", to inspire and engage protesters aspirations and activists from urban and rural areas to gather within major cities (e.g. Cairo) to create an organised uprising. At the same time, citizens used modern technologies to flare up tension and fuel frustration with corruption and unrest with a failing political architecture within the countries. Soon after the Tunisian revolution, the domino effect sprawled in neighbouring Egypt and Libya, which eventually led to the overthrow of Egyptian president Hosni Mubarak and Libya's Muammar Al Qaddafi (Bilal, 2011; Coetzee, 2013; Gelvin, 2012; Snider et al., 2011). Although the vast majority were jubilant after the toppling of previous regimes, there are growing political and religious secular divisions that have left revolutionary Arab societies polarised (Guzansky and Berti, 2013). In Libya, civil divisions have increased, causing social secularisation (Bowen, 2012).

At the time of writing (January 2015), the civil war in Syria continues as armed militia's clash with Bashar Al-Assad's armed forces (Eyadat, 2013; Dalacoura, 2013; Sorensen, 2011). The escalation of a bloody civil war (Landis, 2012) and the insurgency of Islamist extremists shows little sign of ending anytime soon (Van Veen, 2014). A similar scenario is witnessed in Iraq where since the war in 2003, sectarian violence has restricted redevelopments from taking place (Hafedh et al., 2007). The country has experienced conflict amid the insurgency from extremist militants that have taken over large parts of the country (Bayoumy, 2014; Lister, 2014). Protests in Yemen have continued despite the stepping down of their previous leader Ali Abdullah Saleh (Mohammed Ali, 2014). As a result of a failed attempt to overthrow the Bahraini monarchy in 2011, tensions in Bahrain have remained high amid Shia citizens protesting because of a lack of democratic rights, alienation in society and the hegemonic nature of the 'Sunni' (largest denomination of Islam) led government (Ghannam, 2011), which many 'Shia's' (second largest denomination of Islam) considered as favouring Sunni citizens (Ismael and Ismael, 2013; Kamrava, 2012; Sultan, 2013). Petersen et al., (2010) indicates that due to the ME having a lack democratic rights, has led to the minorities taking up arms, protesting against freedom of speech and political tolerance. This aspect of political tolerance has led to such extremist groups like that of Islamic Fundamentalists who 'reject the rights of other groups' belonging to different democratic citizens. Petersen et al., (2010) suggests that Islamic Fundamentalists believe in 'breath of intolerance', that focuses on 'denying others their basic rights' and violence.

At the time of writing, the remainder of the gulf countries (Kuwait, Oman, Qatar, Saudi Arabia and the United Arab Emirates) have been largely unaffected by the revolutions in other ME states (Hess, 2013). Gulf monarchies have not experienced sustained widespread protests (with the exception of Bahrain, which has witnessed a sectarian dilemma), because the monarchies are based upon tribal, clan and family ties and therefore do not face a crisis of legitimacy. 
Furthermore, Gulf monarchies have sustainable social contracts with the majority of their citizens (Forstenlechner et al., 2012). Gulf States such as Qatar and the United Arab Emirates have not witnessed mass protests. Likewise, in Kuwait, the government quickly announced increased salaries for their citizens to minimise the potential for demonstrations (Kamrava, 2012). In neighbouring Saudi Arabia, moderate protests were experienced (AlJazeera, 2011). A 15\% increase in state workers' salaries as well as extra funds for housing, studying abroad and social security was provided by King Abdullah to placate citizenry dissatisfaction. Moreover, after decades of uncompromised law, the Saudi government allocated the right for female citizens to vote for the first time (Khalife, 2011). In Oman, minor demonstrations demanded better social contracts (Massad, 2011). In response, the Sultan followed Saudi Arabia and Kuwait's strategies of increasing working salaries (Forstenlechner et al., 2012).

Apart from the three transitional lead revolutionary nations (Tunisia, Egypt and Libya), North African neighbour, Morocco, saw only a few minor incidents, but King Mohammed VI vowed to amend the constitution to reflect new measures that ensured the authority of the Moroccan parliament (Owais, 2011; Sater, 2012). In Jordan, King Abdullah II appointed a new prime minister and replaced the complete ministerial cabinet with the promise of political reforms (AlJazeera, 2011). Lebanese citizens demanded better economic welfare from their government, who in return handed out economic concessions to citizens (Ottaway, 2011).

The unrest in Egypt and Libya was very dissimilar. Alqudsi-ghabra (2011) indicates that during the unrest in (Tunisia, Egypt and Libya), social media was considered as an accelerator for those activists who wanted to spread chaos and cause epidemic with the region. Technology enabled activists to share their grievances instantaneity and transparency, which give empowerment to the people. This approach allowed actors; activists and communities to share messages simultaneously across a variety of creative devices to overcome government censorship and social media crack down (Eltantawy \& Wiest 2011*; Howard \& Hussain, 2011).

Egypt achieved a political revolution by way of mass protests and demonstrations (Housden, 2013; Pace and Cavatorta, 2012), while Libya saw armed conflict (Brahimi, 2011) and a political revolution. Common causes of unrest in both Egypt and Libya were believed to be a lack of economic freedom, political rights as well as a sense of social injustice (Campante and Davin, 2012). Al Shayji (2012) argued that the revolution phenomenon has led to instability and it must do so in order to transition through times of uncertainty and change. The uncertainty is emphasised by the most recent counter led revolution in Egypt (4th July 2013) also known as an 'epiphenomenon', which saw the removal of Muslim Brotherhood (MB) leader Mohammed Morsi from power. His subjugation was seen as a second revolution by anti-Morsi supporters but a military coup by pro Morsi followers (De Smet, 2014). Abdel Fattah Al-Sisi eventually became the new leader of Egypt after winning the presidential election with $96.1 \%$ of the votes. A similar scenario occurred in Libya, where Prime Minister Ali Zedan stepped down from office. Moreover, Chomsky (2013) criticised the progress of Egypt and Libya thus far, arguing that Libya is struggling to control its militias and that the military in Egypt are returning the country to a state of authoritarianism. For example, rival militias have taken over the capital city Tripoli's Airport and engaged in armed conflict in a bid to gain greater legitimacy and power (Laessing, 2014) while in Egypt, polarisations in society have increased because of differences in political and religious views (Georgy, 2014).

Religious and traditional cultural values are two of the most prominent factors under question in the battle for change in the ME. Although religion as well as cultural traditions vary between ME states, they are deep rooted within ME citizens. Many Arab countries follow Sharia law (such as Saudi Arabia), while others follow a mix of both Sharia law and Civil law (such as Egypt, Sudan and Morocco) (Al-Olayan and Karande, 2000). Hashemi (2011) suggested that the vast majority of Arabs were against the idea of a western style of democracy that followed secularism and citizens supported the idea that Sharia law should be 'a' source although not 'the' source of legislation governing political affairs. Furthermore, Hashemi argued that Arab societies have been dominated by negative experiences of post-colonial authoritarianism. The various modernisation projects and political constitutions granted by authoritarian regimes were often overcast under the umbrella of Arab nationalism. What were the main drivers behind the revolutions in Egypt and Libya? Technology is considered a feature of globalisation (Anderson, 2011; Ghannam, 2011) but media technologies in the form of social media were innovatively used in the call for change. In consuming media technologies, citizens appeared to take on new consumption practices that were previously unseen. The key drivers are discussed in in the next subsection.

\section{Social Media - A Key Driver Behind the Egyptian and Libyan Revolution}

Traditional media technologies (e.g. newspapers, magazines, TV, letters) have been used for decades to disseminate media to the masses. These mediums have provided the platform for citizens to converse with each other and engage in a dialogue. However, in recent years new communication technologies have skyrocketed and become an integral facet of everyday life. Such technologies such as social media via the internet have become useful resources for the mobilisation of collective action and designation of social movements around the world. When the impact of social media is against a political or social causes, this is known as cyber activism (Eltantawy \& Wiest, 2011). In relation to the Egyptian and Libyan revolutions of 2011, an understanding of the impact of social media is needed. This comprises the rest of the discussion in this section.

It would be naïve to assume that one driver was more effective over the other in driving the revolutions forward. On the contrary, this section should be viewed that the 
combination of drivers were significant in driving the revolutions forward. It is beyond the scope of this paper to discuss the drivers beyond introductory parameters. Historically, revolutions such as the French revolution (1789-99) occurred due to an array of issues such as economic struggles, political rights and rising food prices (Sydenham, 1997). Contradicting the French revolution, the spread of media technologies were influenced by the 'domino effect' of the revolutions, beginning with Tunisia, followed by Egypt and then Libya. The downfall of Tunisian leader Ben Ali, sent shockwaves across Egypt which has the $2^{\text {nd }}$ largest internet using population in the region after Iran. Media communications such as the internet and social networking sites like Facebook, Twitter and mobile phones saw a technological eruption during the revolutions (Ray, 2011). Egyptians and Libyan citizens used these methods of communication to build extensive networks, create online social capital, organise mass demonstrations and arrange political action (Ghannam, 2011). However, in Libya, the armed conflict between rebel fighters and the Qaddafi regime meant that the impact of social media was more peripheral than central to overturning the old regime.

Similarly, in Egypt, social media paved the gateway for activists such the 'Tamarod Movement', 'Kefaya' (meaning 'enough' in Arabic) and the 'April $6^{\text {th }}$ Movement' (Zunes, 2014) who disseminated key messages for collective action. Silent protests such as for 'Khaled Said' (an ordinary Egyptian citizen who was allegedly subject to police brutality) also assisted in establishing structured movements against the Mubarak regime. Religious gatherings in places of worship also contributed to awareness and discussion as did activism from different political factions. Social anarchy, chaos, cultural imagery, symbolisms and other forms of artistic expression were ambivalent in both Egypt and Libya (Cavalluzzo, 2011) and were utilised by the people. Graffiti for instance, known as a traditional tool of communication, was everywhere on Egyptian streets but evaded explicit political reference that could compromise the graffiti culprit (Abaza, 2013). Candidness and freedom of expression was exposed during the revolutions, something that was adjudged to be constrained prior to the events. Perhaps the ability to speak out has existed a long time before the internet, social media mechanisms and cultural interactions, yet many individuals in ME societies had not been given an opportunity to cast their own candid views.

In the past, social media was assumed to be relatively insignificant, elitist and selective because of poor internet access numbers in the ME (Rabindranath \& Kapil, 2015). Moreover, state censorship threatened freedom of political expression and constrained citizens in what terms of what could be said publically. Therefore, when the call for a revolution came into play, citizens used blogospheres, online discussions, Facebook, Twitter to vent their anger against their regimes. To its credit, social media assisted in transforming Arab citizens' voices of discontent into a structured movement that epitomised shared values for 'change' (Howard and Hussain, 2011). More importantly, if it is accepted that new acts of consumption emerged via taking part in technological activities (e.g. social media) as well as social activities, then Egyptians and Libyans had taken consumption to a new level. To an extent, the censorship of information may have accelerated citizens' consumption of media technologies.

What made matters worse is when attempts by regimes (e.g. the Mubarak government) attempted to block telecommunications and the internet. This exacerbated citizens desire for change and inspired them to flock to Tahrir Square (protest hotspot in Cairo) in unprecedented numbers (Joseph, 2012) to call for Isqat Al Nism (down with the regime). Many Egyptian citizens also utilised Google maps to pinpoint demonstration locations, while armed rebels in Libya used it to target Qaddafi strongholds. At the time of the Arab Uprising and according to Ghannam (2011), Egypt's “interior ministry" had a team of 45 people who soul job was to monitor and maintain social media (and in particular Facebook) across Egypt. Such a small team monitoring 5 million registered internet users across a region of 80 million Egyptians proved unmanageable and indicates why the Egyptian authorities failed to control social media activity during the events. In a similar vein, Ghannam (2011) further indicated that the use of social media through the use of Twitter enabled Tunisian activists to form micro-blogging details to help mobilize protests right across different regions. The strong influence of social media in the Tunisian revolutions explains why it was so popular amongst Egyptians and the rest of the Arab world. Christensen (2011) agrees with Ghannam (2011) about how the use of social media can be used for the sole purpose of activist organisation and political dissent, the ramifications of which can affect local, national and global politics. Christensen (2011) indicated that Facebook, Twitter and YouTube played a major influence in the Iranian and Egyptian Uprising; even afterwards the Iranian authorities did try to introduce counter measures through the aids of monitoring and firewalls (Software \& Hardware) that was used to repress any other future events.

Lim (2012) suggests that social media has long been present amongst Egyptians and has seen an incremental rise with 54 out of 70 citizens recorded as being active online since 2004 . This could help explain why the gathering of online communities and groups with common interests quickly translated into contemporary populist movement. The use of social media can be seen as expanding people views and social movements depending on people values. Wertsch \& Roediger (2008) suggest that an individual within a community is stimulated to remember by formulating a common set of themes, traits, tools, or by individuality. This could be through an inspirational recollection of historical events which can be applied to people views and social movements. Social media provides the opportunity to concoct a reaction and is driven by citizens' passion. As Lim (2012) indicates: The Kefaya Youth used social media to captivity embraced bloggers and activists with it simple message of "enough", and was able to capture audiences from a diverse spectrum of life and regions, e.g. farmers, women, to professionals. This approach united 
political parties and communities enabling them to use technologies to spread the message for protests using, mobiles, computers, etc... According to Lim (2012) and in agreement with Wertsch \& Roediger (2008), the Kefaya Youth was able to mobilise due to them having a key objective and a common theme which was:

"Injustices of the death of Khaled Said as a martyr was just such a trigger. The group was able to unify its followers by providing a solid 'schemata of interpretation' that enabled individuals "to locate, perceive, identify and label", (Lim 2012, page 241)”.

Looking beyond the citizens' use of social media, business firms have also benefitted from having a firm presence in countries because of it. One of the advantages such firms have is that they can advocate their technologies (social media, mobile \& tablet technologies, Google maps) without having a physical presence in a particular country, thus establishing a borderless virtual sphere (Benmamoun et al., 2012). Although the extent of social media in the revolutions has subsided since the events of 2011, (it was a driver but not the main driver in the Egyptian and Libyan revolutions), online mediums such as
Facebook, YouTube and Twitter will continue to be readily available and therefore virtual sphere multinational firms (e.g. Google, Facebook and Twitter) will continue to have a strong foothold in the ME. Other mediums such as blogospheres were commonly consumed in the five years leading up to the revolutions, but most of them were apolitical and averted most politically charged debates. Regardless the number of drivers present in driving the revolutions forward, regime change would not have been possible without the consumption of new technologies, social activities and the desire to speak out Lim (2012).

\section{Framework "Causes \& Technologies"}

In this section, we illustrate a framework (Fig 1) that can be used to identify factors associated with the revolutions such as the 'Arab Spring' through the use of 'technologies' and 'causes'. The framework is divided into three key areas: Technologies, Human Factor and Schemata of interpretation (Landau, 1980).

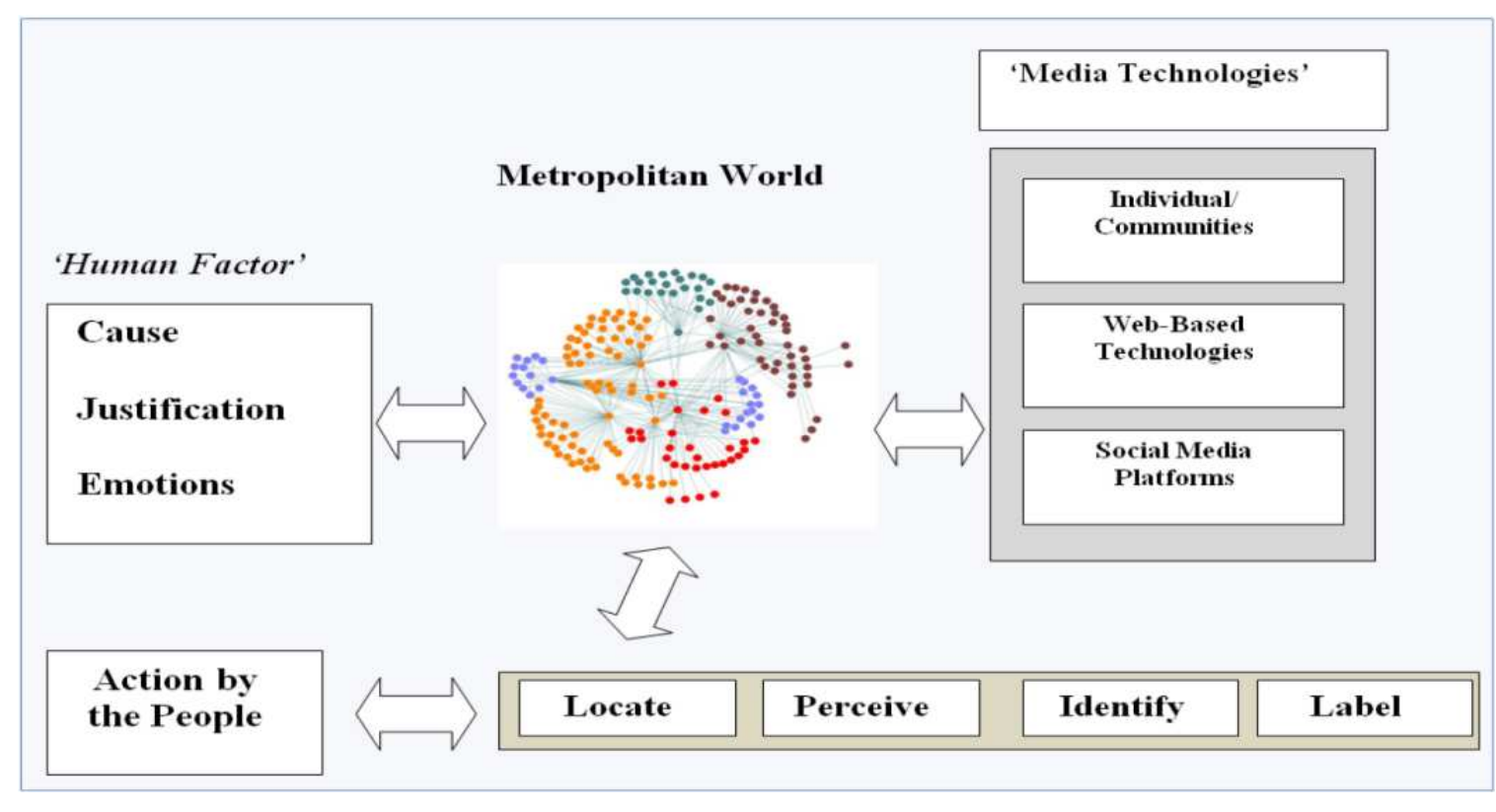

Figure 1. 'Schemata of interpretation'.

Based on Landau's (1980) notion of the 'schemata of interpretation', this framework suggests that individuals (action by the people) took part in what can be considered 'abnormal behaviour' because they actively processed social media information to bring about change. This theoretical proposition has not been examined in a revolutionary context and as such, the importance of this framework in grounded in new context spotting. Similarly, Landau argues that phobic individuals are prepared to digest stimuli from a feared object. In the context of this paper, the feared object was the regime. Therefore, citizens contradicted the notion of being fearful by using new media technologies and subsequently advocating uncharacteristic behaviour. In the next three sub sections, an attempt is made to discuss how individual communities, web-based technologies and social media platforms are important in bringing about change.

\subsection{Media Technologies}

\subsubsection{Individual/Communities}

Rosenbaum (1980) suggests that individuals form into groups, based on similar interests and thoughts. This process of grouping can have a social connecting value by defining criteria of membership and hierarchy through identifying social behaviour and attitudes. Nahapiet and Ghoshal (1998) expand on Rosenbaum (1980) idea about how groups are formed and indicate that a key component within creating a community structure is mutual acquaintance and recognition. Nahapiet and Ghoshal (1998) suggests that by using mutual acquaintance and recognition, individuals within the group 
can have some sort of identity, feeling gratitude, and friendship, thus creating a mutual respect, within a social network. Girvan and Newman (2002) and Stewart (2005) highlights the fact that social networks, offers individuals a freedom to share common experiences and build upon existing communities as mentioned early by Rosenbaum (1980).

Stewart (2005) indicates that technologies can offer individuals a chance of creating a social status through the use of expressing approval or disapproval on a variety of different environmental factors like i.e. belief, cultural, and society. As mentioned by Nahapiet and Ghoshal (1998) disapproval from one group can lead to disharmony from another, which can led to individuals seeking and gathering information outside one's immediate social cluster (Stewart 2005). This source of seeking and gathering information can lead to individuals and communities through the use of technologies to stir up hate (Wertsch \& Roediger 2008; Lim 2012), as seen by the The Kefaya Youth.

\subsubsection{Web-Based Technologies}

According to Garrent (2006) "ICT can alter a community", it has the capabilities of increasing protest activities in one location while issuing salience across a much broader area, through multiple devices, which is why, web-based technologies are challenging the conceptual thoughts of activists in the ways they think, communicate, unite, and bring together a show of strength (Hara \& Huang 2013). Farinosi \& Trere (2010) suggests that social movements continuously operate through a shifting world and those web-based technologies enable social activists to explore the best medium to get their message across.

\subsubsection{Social Media Platforms}

The use of Social Media Platforms, like that of Twitter, YouTube, Facebook and others, according Ghannam (2011), Christensen (2011) \& Klerks (2001) can influence how activists organise and influence people's thoughts about local, national and global politics/events, which can have a direct human impact. Hara \& Hung (2013) indicates that social media can help activists to take advantages over the many new innovative features like Google maps, real time TV and YouTube for sharing propaganda materials.

\subsection{Human Factor}

\subsubsection{Cause}

According to Klerks (2001), Cause can be affected by 'ethnic or tribalties, family relations or common backgrounds in a geographical (neighbourhood) or society'(p38). Farinosi \& Trere (2010) agree with Klerks (2001) and indicate that there needs to be some shared beliefs and solidarity, before justification can be made. Hara \& Huang (2013) have similar ideas to Farinosi \& Trere (2010) and Klerks (2001) but indicate that solidarity through "action-oriented", which refers to "meaning and validate" can inspire others to join the cause. Once the individuals have united within a common cause, then this can establish a justification for the activists (Actors) to carry out demonstrations and uprisings.

\subsubsection{Justification}

Lim (2012), Farinosi \& Trere (2010) and Wertsch \& Roediger (2008) suggest that individuals within a community can stimulate justification of an uprising by formulating a common set of themes, traits or an event (historical or current), which can be applied to people's views and social movements within society to stir up hate, or if they are passionate over something. By justifying the demonstrations through themes, this would allow others people within the area to engage and share their views of discontent (Nahapiet and Ghoshal 1998; Wertsch \& Roediger 2008; Lim 2012).

\subsubsection{Emotions}

Garrett (2006) suggests that emotions can be affected by specific grievances, or a passion towards relationship (in Nye 2010). The main goal of emotions is to indicate that people through grievances or passion have the power to seek social change and alter the relations of power and with the low cost of technologies, protesters only need a few people at first and with aid of global media can soon create a collective movement to get their voice heard (Hara \& Huang 2013). Hall (2007) indicates that not all activists can construct a rational argument; or create a clear form of communication that is formal, orderly, and contained that can challenge democracy through the use of altruism, compassion, or moral sentiment to motivate and enable people to work together in hopes of improving the lives of all.

\subsection{Schemata of Interpretation}

\subsubsection{Locate}

According to Farinosi \& Trere (2010) Social Media has enabled activists to greatly facilitate the mobilization of protests, such as national street demonstrations while giving the activists a more glamorous transition. Hara \& Huang (2013) suggest that using this approach, individuals can quickly coordinate local and international protests as seen in the ME. Benford and Snow (2000, p12) suggest,

"Hypothetically, the more central or salient the espoused beliefs, ideas, and values of a movement to the targets of mobilization, the greater the probability of their mobilization"

This shows that activists can quickly merge upon areas that would not of been previously covered and converge with other fractions to demonstrate their emotions, beliefs, and disloyalty to rally additional support to gain momentum within the protest.

\subsubsection{Perceive}

Benford \& Snow (2000) indicates that 'perceive' would be defined as a way of creating a tactical way of bringing people together through beliefs/claims and giving them a sense of transparency. Gillan (2008) suggests that by activating a relationship through defining a cognitive structure (being together), can frequently increase the credibility of the issues and affect the mobilization of the activists.

\subsubsection{Identify}

Activists can be identified through literature as a movement of 'time and space', which over time, can strain and break 
down humanity through weakened social depravities and frustrations (Buechler 2004). It is important within the framework to identify, groups that can contribute to any unsettling social-structural changes through emergence of protest waves (Koopmans 2004). By identifying the movement, belief, cause, justification, tactics according to Buechler (2004) and Koopmans (2004) can be used as a way to challenge and manipulate the mobilisation of the group before bringing it under control.

\subsubsection{Label}

According to Oliver \& Johnson (2000), Label as an Actor can be seen as an "ideology of political beliefs, that can be associated with the "dominants' defence of their privileges versus those who challengers to a dominant system" (p.4). As suggested by Oliver \& Johnson (2000) and Rucht (2004) this would allow activists to bring in strong traditions of belief and culture to unify individuals into creating coalitions that can extend and bound multiple memberships of activists together, creating alliances. This way enables activists to appeal to the public through the use of Social Media to embarrass the target, to effectiveness highlight the cause to make it newsworthy (Gamson 2004).

\section{Conclusion}

In this paper, we have explored the Arab Spring', while studying the impact of social media on the revolution through the use of technology. Through the "Causes \& Technologies" framework, we have illustrated the important factors associated with the uprising by providing a mechanism that enables us to identify the human factors and causes in which individuals and communities would challenge an existing system or a way of living. Of course, each system is made up of varying political structures and in the case of Egypt and Libya, the common themes of authoritarianism and political autocracy acted as catalysts and accelerated citizens' desires for change. The very nature of going against such structures would seem unfeasible and unheard prior to the introduction of social media. Therefore, new media technologies have paved the way for a potentially more candid level of political expression. Moreover, social media is borderless and by definition requires no mass public mobilisation. Rather, the congregation of the masses online can be used to support change. When this fails, then online activism can lead to mass public demonstrations. The combination of the two can be considered to have a more profound effect on the occurrence of a revolutionary scenario. Future development of the causes and technologies framework would be applying it to a different uprising in the ME or other settings such as the Crimea crisis. Further research could also investigate what other drivers in combination with social media are influential in driving people to strike change. Building on the work of Landau (1980), it would also be interesting to see how the Schema of Interpretation would differ across different settings and indeed how effective social media is in promoting change. This would involve a multi-disciplinary lens across both sociology and psychology.

\section{References}

[1] Abaza, M. (2013). Walls, Segregating Downtown Cairo and the Mohammed Mahmud Street Graffiti. Theory, Culture \& Society, 30(1), 122-139.

[2] AlJazeera. (2011). 'The Arab awakening, Tunisia, Egypt, Libya, Bahrain: A roundup of the popular protests that have swept the region over the last few months,' Available at : $<$ http://www.aljazeera.com/indepth/spotlight/2011/02/201122 2121213770475.html>. (accessed 10/02/12).

[3] Al-Olayan, F.S., \& Karande, K. (2000). A content Analysis of Magazine Advertisements from the United States and the Arab World. Journal of Advertising, 29(3), 69-82.

[4] Alqudsi-ghabra, T., (2011). Creative use of Social Media in the Revolutions of Tunisia, Egypt \& Libya, International Journal of Interdisciplinary Social Sciences, Volume 6, Issue 6, pp.147-158. 2011.

[5] Al Shayji, A. (2012). 'Fate of Arab Spring is key to people's future prospects, Available at: $<$ http://gulfnews.com/opinions/columnists/fate-of-arab-springis-key-to-people-s-future-prospects-1.996482>. . (accessed $06 / 06 / 14)$

[6] Anderson, L. (2011). Demystifying the Arab spring: parsing the differences between Tunisia, Egypt, and Libya. Foreign Affairs, 90(3), 2-7.

[7] Arendt, H. 2006 [1963]. On Revolution. London: Penguin Books.

[8] Argyrou, V. (2013). The Gift of European Thought and the Cost of Living: Berghahn Books.

[9] Bayoumy, Y. (2014). 'Syria-Iraq 'caliph' incites Muslims to holy war,' Available at: $<$ http://uk.reuters.com/article/2014/07/01/uk-iraq-security-bag hdadi-idUKKBN0F64RC20140701>. (accessed 10/07/14).

[10] Benford, D. R., \& Snow, A. D. (2000). Framing Processes and Social Movements: An Overview and Assessment. Annual Review of Sociology, 26, 611-639.

[11] Benmamoun, M., Kalliny, M., \& Cropf, R.A. (2012). The Arab Spring, MNE's and virtual public spheres. Multinational Business Review, 20(1), 26-43.

[12] Bilal, M. (2011). The Arab awakening, Available at: $<$ http://www.aljazeera.com/indepth/spotlight/aljazeeratop1020 11/2011/12/2011122619534967270.html>. $\quad$ (accessed $05 / 01 / 12)$.

[13] Brahimi, A. (2011).Libya's Revolution. Journal of North African Studies, 16(4), 605-624.

[14] Bremmer, I., (2010). The end of the free market: who wins the war between states and corporations? European View, Vol (9: 129), 2010. DOI 10.1007/s12290-010-0129-z, Centre for European Studies 2010.

[15] Buechler, M. S. (2004). Chapter 3, Strain and breakdown theories, Edited by Snow, A. D., Soule, A. A., \& Kriesi, H, The Blackwell Companion to Social Movements, 2004. 
[16] Butt, G. (2011). Awaiting the Arab Summer. Energy and Geopolitical Risk, 2(4), 7-11.

[17] Campante, F. R., \& Chor, D. (2012). Why was the Arab World Poised for Revolution? Schooling, Economic Opportunities, and the Arab Spring. The Journal of Economic Perspectives, 26(2), pp. 167-187.

[18] Cavalluzzo, J. (2011). Egypt's Cultural Revolution. Social Policy, 41(4), 75-77.

[19] Chomsky, N. (2013). 'Arab Spring, Three Years on,' Available at:

$<\mathrm{http} / / /$ www.social-europe.eu/2013/11/arab-spring-three-years 1>. (accessed 10/12/13).

[20] Eltantawy, N., \& Wiest, B. J., (2011). The Arab Spring| Social Media in the Egyptian Revolution: Reconsidering Resource Mobilization Theory. International Journal of Communication, 5,18 .

[21] Eltantawy, N., \& Wiest, B. J., (2011)*. Social Media in the Egyptian Revolution: Reconsidering Resource Mobilization Theory

[22] International Journal of Communication 5 (2011), Feature 1207-1224, 2011

[23] Christensen, C. (2011). Twitter Revolutions? Addressing Social Media and Dissent

[24] The Communication Review. Volume 14, Issue 3, 2011. 155-157.

[25] Coetzee, E. (2013). Democracy, the Arab Spring and the Future (Great Powers) of International Politics: A Structural Realist Perspective. Politikon: South African Journal of Political Studies, 40(2), 299-318.

[26] Dalacoura, K. (2013). The Arab Uprisings Two Years On: Ideology, Sectarianism and the Changing Balance of Power in the Middle East. Insight Turkey, 15(1), 75-89.

[27] Daou, F. (2011). The Arab uprisings and the new challenges for national social cohesion and Arab-West relations. Adyan CCE Conference at Louaizé, Lebanon. 2-3 June, 2011.

[28] De Smet, B. (2014). Revolution and Counter-Revolution in Egypt. Science \& Society, 78(1), 11-40.

[29] Eyadat, Z. M. (2013). Fiqh Al-Aqalliyyât and the Arab Spring: Modern Islamic theorizing. Philosophy \& Social Criticism, 39(8), 733-753.

[30] Farinosi, M., \& Trere, E. (2010). Inside the. "People of the Wheelbarrows": Particioation between online and offline dimension in the post-quake social movement. The Journal of Community Informatics, 6(3), 2010.

[31] Forstenlechner, I., Rutledge, E., \& Alnuaimi, R. S. (2012). The UAE, the "Arab Spring" and Different Types of Dissent. Middle East Policy, 19(4), 54-67.

[32] Friedman, G. (2011). 'Re-examining the Arab Spring,' Available $<$ http://www.stratfor.com/weekly/20110815-re-examining-ara b-spring $>$. (accessed 12/01/13).

[33] Gamson, A, W. (2004). Chapter 11, Bystanders, public opinion, and the media. Edited by Snow, A. D., Soule, A. A., \& Kriesi, H, The Blackwell Companion to Social Movements, 2004
[34] Gelvin, J. L. (2012), “The Arab uprisings: what everyone needs to know," New York, Oxford University Press.

[35] Georgy, M. (2014). 'Set to rule divided Egypt, Sisi faces biggest test,' Available at: $<$ http://www.reuters.com/article/2014/05/25/us-egypt-election -sisi-idUSBREA4O07F20140525> (accessed 18/07/14).

[36] Ghannam, J. (2011). Social MEdia in the Arab World: Leading up to the Uprisings of 2011,

[37] A Report to the Center for International Media Assistance. http://www.databank.com.lb/docs/Social\%20Media $\% 20$ in $\% 20$ the $\% 20$ Arab $\% 20$ World $\% 20$ Leading\%20up $\% 20$ to $\% 20$ the $\% 20$ Uprisings\%20of\%202011.pdf

[38] Garrent, K. R. (2006). Protest in an Information Society: A Review of Literature on Social Movements and New ICTs. Information, Communication and Society, 9(2), 202-224.

[39] Gillan, K. (2008). Understanding Meaning in Movements: A Hermeneutic Approach to Frames and Ideologies. Social Movement Studies, 7(3), 2008. 247-263

[40] Girvan, M. \& Newman, J. E. M. (2002). Community structure in social and biological networks, Applied Mathematics, Proc Natl Acad Sci U S A. 2002 Jun 11; 99(12): 7821-7826. doi: 10.1073/pnas. 122653799

[41] Guzansky, Y., \& Berti, B. (2013). Is the New Middle East Stuck in Its Sectarian Past? The Unspoken Dimension of the "Arab Spring. Orbis, 57(1), 135-151.

[42] Hall, C. (2007). ReRecognizing the Passion in Deliberation: Toward a More Democratic Theory of Deliberative Democracy. Hypatia, Vol 22, No. 4, Democratic Theory, Wiley, Hypatia, Inc.81-95,

[43] Hara, N., \& Huang, B-Y.(2013). Online Social Movements, Chapter 10, Annual Review of Information Science and Technology, 45(1), 2013.

[44] Hafedh, M., Akoum, A., Zbib, I.J., \& Ahmed, Z.U. (2007) Iraq: Emergence of a new nation from the ashes. International Journal of Emerging Markets, 2(1), 7-21.

[45] Hashemi, N. (2011). The Arab revolution of 2011: reflections on religion and politics. Insight Turkey, 13(2), 15-21.

[46] Hess, S. (2013). From the Arab Spring to the Chinese Winter: The institutional sources of authoritarian vulnerability and resilience in Egypt, Tunisia, and China. International Political Science Review, 34(3), 254-272.

[47] Housden, O. (2013).Egypt: Coup d'Etat or a Revolution Protected? RUSI Journal, 158(5). 72-78.

[48] Howard, P.N., \& Hussain, M.M. (2011). The upheavals in Egypt and Tunisia- The role of Social Media. Journal of Democracy, Vol. 22(3), 36-49.

[49] Inayatullah, S. (2011). The Arab spring: what's next. World Affairs, 15(3), p36-41.

[50] Ismael, J. S., \& Ismael, S. T. (2013). The Arab Spring and the uncivil state. Arab Studies Quarterly, 35(3), 229-240.

[51] Joseph, S. (2012). Social media, political change and human rights. Boston College International and Comparative Law Review, 35(1), 145-188. 
[52] Kamrava, M. (2012). The Arab Spring and the Saudi-led counterrevolution. Foreign Policy Research Institute, 56(1), 96-104.

[53] Khalife, N. (2011). 'Getting the vote could herald real change for Saudi women,' Available: $<\mathrm{http} / /$ www.guardian.co.uk/commentisfree/2011/sep/27/votesaudi-women-king-abdullah $>$. (accessed 22/11/11).

[54] Klerks, P. (2001). The Network Paradigm Applied to Criminal Organisations:Theoretical nitpicking or a relevant doctrine for investigators? Recent developments in the Netherlands, Connections 24(3): 53-65, Insna.

[55] Koopman, R. (2004). Chapter 2, Protest in Time and Space: The Evolution of Waves of Contention Edited by Snow, A. D., Soule, A. A., \& Kriesi, H, The Blackwell Companion to Social Movements, 2004.

[56] Laessing, U. (2014). 'Libyan militia tighten control of Tripoli Airport,' Available at $<$ http://uk.reuters.com/article/2014/07/15/uk-libya-violence-id UKKBN0FK04V20140715>. (accessed 18/07/14).

[57] Landau, R. J. (1980). The role of semantic schemata in phobic word interpretation. Cognitive Therapy and Research, 4(4), 427-434.

[58] Lim, M. (2012). Clicks, cabs, and coffee houses: Social media and oppositional movements in Egypt. Journal of Communication ISSN 0021-9916.

[59] Lister, C. (2014). 'Isis: What will militant group do next?' Available

$<$ http://www.bbc.co.uk/news/world-middle-east-28053489> (accessed 30/06/14).

[60] Lynch, M. (2011). The big think behind the Arab Spring. Foreign Policy, 190, 46.

[61] Massad, J. (2011), 'The Arab Spring and other American Seasons,' Available at: http://www.aljazeera.com/indepth/opinion/2012/08/20128297 2539153865.html. (accessed 10/07/14).

[62] Mohamed Ali, T. (2014). Post-political Transitions in Arab Spring Countries: The Challenges. Procedia - Social and Behavioral Sciences, 109, pp. 250-256.

[63] Nahapiet, J. \& Ghoshal, S., (1998). Social Capital, Intellectual Capital, and the Organizational Advantage, The Academy of Management Review, Vol. 23, No. 2 (Apr., 1998). 242-266.

[64] New Statesman. (2011), "The New Arab Revolt," Available at:

[65] <http://www.newstatesman.com/blogs/the-staggers/2011/01/ar ab-islamist-egypt-democracy $>$ (accessed 06/06/15).

[66] Noueihed, L., \& Warren, A. (2012). The battle for the Arab spring: Revolution, counter revolution and the making of a new era: Yale University Press.

[67] Nye, M. (2010). A life remembered: The voice and Passions of Feminist Writer and Community Activist Flora Kimball. University of California Press, Journals, Digital Publishing,
California History, Vol. 87, No 4(2010). 48-65, 68-71.

[68] Oliver, E. P., \& Johnston, H. (2000). What a Good Idea! Frames and Ideologies in Social Movement Research. Mobilization, 4, 2000. 37-54.

[69] Owais, R. (2011).Arab media during the Arab Spring in Egypt and Tunisia: Time for change. Middle East Media Educator, $1(1), 7-13$.

[70] Pace, M., \& Cavatorta, F. (2012). The Arab Uprisings in Theoretical Perspective-An Introduction. Mediterranean Politics, 17(2), 125-138.

[71] Petersen, M., Slothuus, R., Stubager, R., \& Togeby, L., (2010). Freedom for All? The Strength and Limits of Political Tolerance. B.J.Pol.S.41, 581-597 Copyright Cambridge University Press, 2010

[72] Rabindranath, M., \& Kapil, S. (2015). Social Media and the Arab Spring. Media Watch, 6(1), 124-132.

[73] Ray, T. (2011). The 'story' of digital excess in revolutions of the Arab Spring. Journal of Media Practice, 12(2), 189-196.

[74] Rosenbaum, E. J. (1980). Social Implications of Educational Grouping, Review of Research in Education Vol. 8 (1980). 361-401.

[75] Rucht, D. (2004). Chapter 9, Movement Allies, Adversaries, and Third Parties, Edited by Snow, A. D., Soule, A. A., \& Kriesi, H, The Blackwell Companion to Social Movements, 2004

[76] Sakbani, M. (2011). The revolutions of the Arab Spring: are democracy, development and modernity at the gates? Contemporary Arab Affairs, 4(2), 127-147.

[77] Sater, J. N. (2012).The Arab spring and democratization in Morocco. Orient, 53(1), 30-37.

[78] Snider, E.A., \& Faris, D.M. (2011). The Arab Spring: U.S. democracy promotion in Egypt. Middle East Policy, 18(3), 49-62.

[79] Sorensen, D.S. (2011). Transitions in the Arab World Spring or Fall? Strategic Studies Quarterly, Fall 2011, 22-49.

[80] Stewart, D. (2005). Social Status in an Open-Source Community, American Sociological Review, American Sociological Review October 2005 vol. 70 no. 5 823-842

[81] Sultan, N. (2013).Al Jazeera: Reflections on the Arab Spring. Journal of Arabian Studies, 3(2), 249-264.

[82] Tadros, M. (2012). Introduction: the pulse of the Arab revolt. IDS Bulletin, 43(1), 1-15.

[83] Wertsch, V. James., \& Roediger, L. H. (2008). Collective memory: Conceptual foundations and theoretical approaches, Memory, 16(3), 318-326.

[84] Zunes, S. (2014). 'Regime Repression and Paranoia Grows in Egypt,' Available at: $<$ http://www.huffingtonpost.com/stephen-zunes/regime-repres sion-and-par_b_4881403.html >. (accessed 06/06/14). 